\title{
Theoretical Repositioning of Automated Remote Sensing Archaeology: Shifting from Features to Ephemeral Landscapes
}

DYLAN DAVIS (D)

\section{] $\mathrm{u}[$ ubiquity press}

\begin{abstract}
Automated remote sensing has made substantial breakthroughs for archaeological investigation. Over the past 20 years, the reliability of these methods has vastly improved, and the total number of practitioners has been increasing. Nonetheless, much of the work conducted, to date, focuses almost exclusively on specific topographic features and monumental architecture, ignoring the potential of automation to readily assess more ephemeral components of the archaeological record. Likewise, the emphasis on specific feature types overlooks broader landscape patterns, thus delegating automated remote sensing analysis as a method in and of itself, mostly disconnected from larger archaeological and anthropological investigations. Here, I review recent attempts to rectify this shortcoming by using automated analysis methods to record and explain ephemeral archaeological material distributions. While such research is limited, I argue that the successes achieved in these recent studies offer a pathway forward for automated remote sensing to become more fully integrated with archaeological work beyond the detection of specific topographically distinct features.
\end{abstract}

CORRESPONDING AUTHOR:

\section{Dylan Davis}

The Pennsylvania State

University, US

dsd40@psu.edu

\section{KEYWORDS:}

automated image analysis; machine learning; remote sensing; archaeology; landscape archaeology; archaeological theory

TO CITE THIS ARTICLE:

Davis, D. 2021. Theoretical Repositioning of Automated Remote Sensing Archaeology: Shifting from Features to Ephemeral Landscapes. Journal of Computer Applications in Archaeology, 4(1), 94-109. DOI: https://doi. org/10.5334/jcaa.72 


\section{INTRODUCTION}

Remote sensing archaeology has a long history and improvements in sensing technologies and data analysis methods have greatly expanded our ability to record archaeological data (Adamopoulos and Rinaudo 2020; Lambers 2018; Luo et al. 2019; Osicki and Sjogren 2005; Verhoeven 2017). One of the most significant methodological advances in archaeological remote sensing, in recent years, has been the development of automated techniques for landscapelevel archaeological prospection (Davis 2019; Lambers, Verschoof-van der Vaart and Bourgeois 2019; Traviglia and Torsello 2017). In recent reviews of automated remote sensing in archaeology, a clear pattern emerges within the use of these methods, specifically an intense focus on the detection of individual features, oftentimes "monumental" constructions such as mound complexes, large-architectural features, or other topographically distinct remnants of human activity (e.g., charcoal kilns, craters of war, etc.) (e.g., Magnini, Bettineschi and De Guio 2017; Schneider et al. 2015; Trier, Cowley and Waldeland 2019; Wang et al. 2017).

While nearly all published case studies utilizing automated detection are focused on explicitly noticeable landscape modifications, such large-scale features do not comprise most of the archaeological record. Of course, there is a very good reason for why most archaeological applications of AI and automation are restricted to such types of features: they are distinct, unique from surrounding landscapes, and easy to detect. It is also important to note that with the continued struggle by researchers to limit false positive results within archaeology and heritage management, developing and refining automated techniques has required target features that are simpler to detect in terms of their morphology. In addition, the lack of high-resolution data until more recently made detecting anything else largely a dream rather than an achievable reality. Nonetheless, researchers have made great strides in automatically detecting cultural features from remotely sensed data, but research affixed to dominant landscape features can come at the expense of broader understandings of human occupancy and its connection to ecological conditions throughout the world (which remains poor in many regions, see Stephens et al. 2019).

Thus, a pivotal question for researchers focused on automated workflows for archaeological investigations is how useful this niche really is for archaeology if all we can do is locate the largest or most morphologically uniform displays of cultural activity? This echoes a recent sentiment of Palmer $(2020,26)$ who states that researchers "have been doing the same thing, maybe with different algorithms, for at least 10 years... Show me that [automated detection] works on those sites with 'no shape' and I'll begin to believe [in these methods' usefulness]."
With this sentiment in mind, a shift of automated remote sensing in archaeology beyond individual features to broader and more complex patterns of human activity, cultural niche construction, and landscape modification could greatly enhance the utility of these methods. If we begin to take the knowledge gained by previously successful efforts for automated archaeological prospection and refocus on a multi-scalar landscape perspective attuned to ephemeral archaeological deposits and broader patterns of landscape use (also see Doneus 2013; Traviglia and Torsello 2017), we may be able to greatly improve our understanding of the true impact that ancient populations had on landscapes.

Recently, there have been attempts to using machine learning for predictive modeling and the detection of subtle archaeological deposits with few - if any - structural remains. Some examples are "indirect" approaches (sensu Davis and Douglass 2020; Howey et al. 2020) for locating archaeological materials (e.g., Davis et al. 2020a), while others have successfully detected features like dung deposits and remnants of farming communities where no structures still stand (e.g., Thabeng et al., 2020; Thabeng, Merlo, \& Adam, 2019). For these "direct" approaches for archaeological prospection, the use of multi- and hyper-spectral sensors at extremely high spatial resolutions was key to their success. While the use of spaceborne sensing for the detection of such archaeological deposits is still new, it offers an unparalleled ability to reconstruct past settlement patterns and landscape use on a vast geographic scale. Such advancements also offer unique opportunities to better integrate automated remote sensing methods into broader archaeological research agendas beyond prospection. In what follows, I review some of these recent applications and discuss the implications of such methodological breakthroughs on the advancement of anthropological and archaeological theory.

\section{A BRIEF HISTORY OF AUTOMATION IN LANDSCAPE ARCHAEOLOGICAL REMOTE SENSING}

Remote sensing archaeologists first began to experiment with automated methods of feature extraction about 20-30 years ago with the development of object-based image analysis (OBIA) and statistical machine learning algorithms for image analysis (Davis 2019; Lambers and Traviglia 2016). However, when considering the use of remote sensing data for the creation of archaeological predictive models, the use of semi-automated remote sensing within archaeology expands several decades earlier (e.g., Custer et al. 1986; Drager 1983; Findlow and Confeld 1980; Jones 1979; Madry and Crumley 1990).

Landscape classification has long been a staple of remote sensing analysis, and archaeologists have used 
such methods for the purpose of exploring settlement patterns and expediting survey projects since the 1980s (e.g., Custer et al., 1986); such methods continue to persist today (e.g., Abate et al. 2020; Davis et al. 2020a; Kirk, Thompson and Lippitt 2016; Klehm et al. 2019). Automated methods for direct feature extraction begin in the mid-1990s (Lemmens, Stančić and Verwaal 1993; also see Lambers and Traviglia 2016), at which point there is a gap in publications until the early $21^{\text {st }}$ century, at which point the use of mathematical algorithms begin to gain prominence in locating ancient Roman roadways and mounded architecture in aerial imagery (Bescoby 2006; Menze, Ur and Sherratt 2006). From this point, dozens of case studies assessing various methods were published trying to maximize ways of accurately extracting information relevant for cultural heritage management from remotely sensed data (e.g., De Laet, Paulissen and Waelkens 2007; Jahjah et al. 2007; Magnini, Bettineschi and De Guio 2017; Sevara et al. 2016; Trier, Larsen and Solberg 2009). While some researchers achieved remarkably accurate results (e.g., Caspari and Crespo 2019; Guyot, Hubert-Moy and Lorho 2018), many struggled with issues of false positive and negative errors, leading some researchers to question the efficacy of such methods for archaeological work (e.g., Casana 2014; Hanson 2010; Parcak 2009). With the advent of deep learning models (a branch of machine learning), specifically those based on convolutional neural networks (CNNs) - a model architecture that makes use of multidirectional data analysis for pattern recognition - the issue of accuracy is beginning to diminish, but challenges still remain (e.g., Bonhage et al. 2021; Caspari and Crespo 2019; Garcia-Molsosa et al. 2021; Somrak, Džeroski and Kokalj 2020; Soroush et al.
2020; Trier, Cowley and Waldeland 2019; Verschoof-van der Vaart and Lambers 2019).

Today, there are fewer pushbacks against automation for remote sensing analysis in archaeology (cf. Palmer 2020), as these methods have greatly improved in their reliability. Nonetheless, the standard formula for such studies is simply to develop a method and report results, but never really mention the function of such methodological advances in the face of broader archaeological questions (Davis 2019; Davis and Douglass 2020). Furthermore, many automated remote sensing archaeological case studies focus exclusively on monumental architecture (e.g., mounds, tombs, medieval castles, roadway systems, palaces and urban complexes) or topographically distinct features like charcoal kilns and burning pits (e.g., Bonhage et al. 2021; Caspari and Crespo 2019; Davis, Sanger and Lipo 2019; Guyot, Hubert-Moy and Lorho 2018; Masini et al. 2018; Schneider et al. 2015; Somrak, Džeroski and Kokalj 2020; Trier, Reksten and Løseth 2021). Ultimately, these foci limit the inherent utility of automated approaches to archaeological remote sensing, as this research leaves little direct impact on archaeological inquiry, but rather stays within a niche methodological focus within remote sensing analysis (Figure 1). By expanding the use of automated remote sensing to greater portions of the archaeological record, these tools have the potential to become more fully integrated into archaeological research focused on a myriad of important questions.

While a great deal of space can be taken to discuss the many advances of automated methods in archaeology, as others have recently done (see Davis 2019; Lambers, Verschoof-van der Vaart and Bourgeois 2019; Traviglia and Torsello 2017), I will focus exclusively

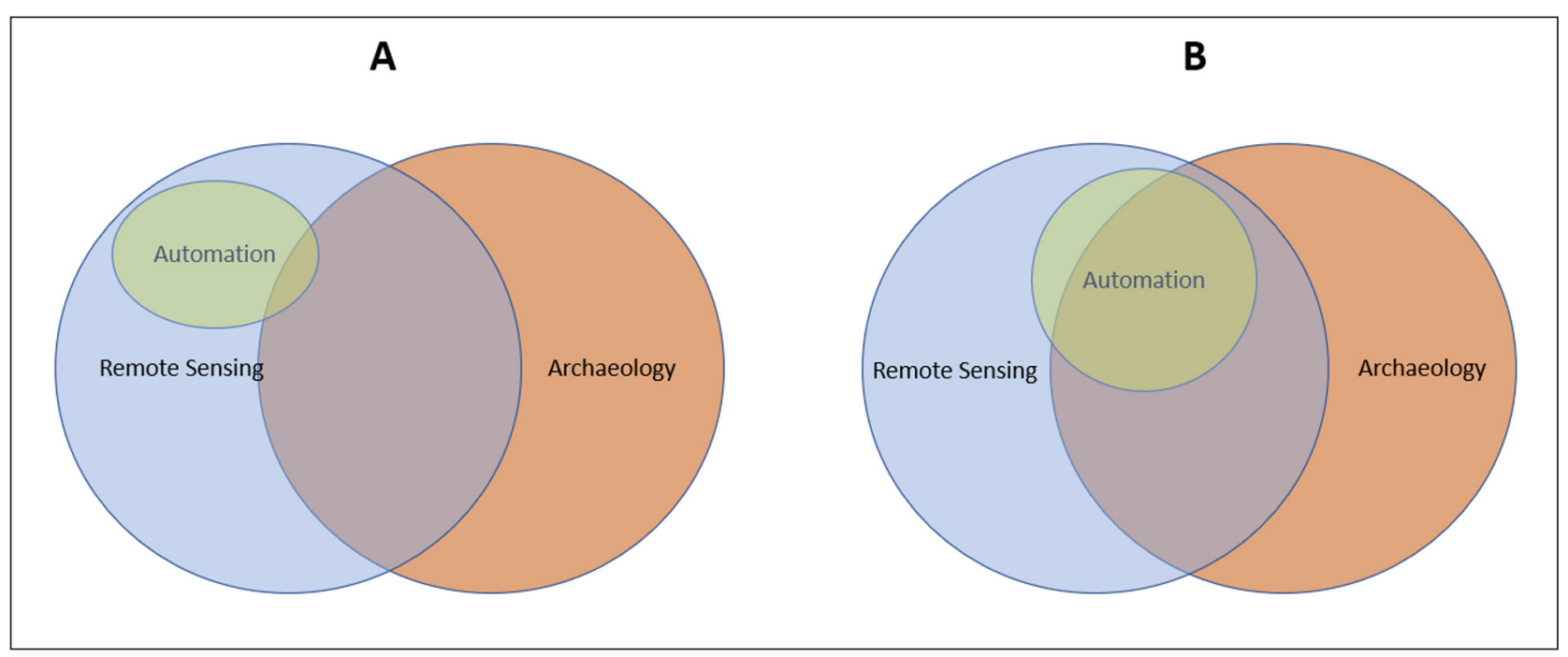

Figure 1 Illustration of how automated methods have integrated within archaeological research. A: Current state of automated remote sensing archaeology, where automation makes many methodological contributions to remote sensing, but few direct benefits to archaeological research more generally. B: Proposed future of automated approaches in remote sensing archaeology, wherein automated techniques play direct roles in larger archaeological research projects beyond merely technical advances to remote sensing analysis. 
on a select subset of applications of machine learning and automation that have received far less attention: the prospection of ephemeral archaeological remains.

\section{A SHIFT TOWARDS THE EPHEMERAL}

Archaeological research has long been challenged by taphonomic processes (Schiffer 1983; Schiffer, Sullivan and Klinger 1978; Schon 2002), and even among remote sensing archaeologists this problem has been noted in the strive towards improving automated archaeological analyses (see Magnini and Bettineschi 2019). The loss of history to the sands of time is a problem not easily solved, and the degradation of many traces of past human activity has long limited our understanding of the earliest human societies. For example, foraging societies, whose archaeological traces are often more discrete when compared with agropastoral or industrial populations, make up some of the least well-documented and understood archaeological cultures from a landscape perspective (see Stephens et al. 2019).

\section{AUTOMATION AND SEMANTIC CONSISTENCY}

In many ways, issues of taphonomy (e.g., multifinality and equifinality) are not circumventable by any suite of methods. However, we can rethink how to use the tools at our disposal to improve our capacity to recognize those sites that are disappearing (Magnini and Bettineschi 2019). This issue is discussed at length by Magnini and Bettineschi (2019), who discuss the implications of depositional processes on the characteristics of archaeological materials (i.e., equifinality and multifinality). The authors state that:

...having a clear picture of how an ancient context should have looked like is not enough. One needs to be aware of the possible modifications that occurred during the millennia to develop an efficient conceptualized model that can be translated in machine language and used to maximize the results of a semi-automatic image analysis (Magnini and Bettineschi 2019: 13).

Magnini and Bettineschi (2019) propose the use of Diachronic Semantic Models (DhSMs) to help address questions about the evolution of archaeological materials in the face of taphonomic activities. In brief terms, DhSMs are a type of ontological system (sensu Guarino et al., 2009), meaning that it constitutes a formalized model by which we can conceptualize the archaeological record in its many forms. There are numerous sources of bias that can affect data collection and the results of different research agendas, and formalized conceptual frameworks can aid in replicability of research and interoperability of datasets (Nuninger et al. 2020a, 2020b). DhSMs are one form of formalized conceptual framework that are designed to create a link between theoretical notions of taphonomic effects and digital representations of these materials in remote sensing data (Magnini and Bettineschi 2019; also see Arvor et al. 2019). By formalizing our expectations of what modifications may have taken place to cultural materials, we can improve our capacity to predict and identify these features within the modern landscape, as it widens our expectations of the form that these materials may take given changes over time. The same has recently been advocated by Nuninger et al. (2020a, 2020b), who develop conceptual frameworks for identifying and tracing movement via "pathways" in the archaeological record. By formalizing our conceptions of these cultural phenomena, it allows for researchers to improve their interpretations of archaeological data by rethinking the scales at which they investigate certain concepts. As I explain below, such conceptualizations are key for improving automated archaeological remote sensing methods and broadening their impact to archaeology by situating these approaches within explicit archaeological theoretical frameworks.

Uncovering more ephemeral traces of human activities is challenging because the nature of habitat modifications and material remains - often consisting of temporary or semi-permanent living structures that decay shortly after abandonment - are far more subtle when compared with cultural features like monuments. The long-term effects of depositional processes will ultimately reduce such materials into microscale traces that require a multitude of different analytical methods to perceive (Davis, Seeber and Sanger 2020). However, recent successes of automated remote sensing bring a suite of advantages to documenting land-use practices in a systematic and replicable manner, and recently this has included the identification of ephemeral land-use activities (Davis et al. 2020a; Orengo and Garcia-Molsosa 2019; Thabeng, Merlo and Adam 2019, 2020).

\section{MACHINE LEARNING AND THE DIRECT DETECTION OF NON-STRUCTURAL ARCHAEOLOGICAL ELEMENTS}

One key example of how automated remote sensing analysis is beginning to allow for the direct documentation of ephemeral archaeological sites is through machine learning and UAV imagery. Orengo and Garcia-Molsosa (2019) demonstrate how drone images can be flown on paths conforming to traditional survey transects to record artifact scatters commonly associated with most archaeological surface investigations. They demonstrate how UAV survey can vastly outperform pedestrian survey strategies and even generate more accurate artifact counts in areas with vegetative obstructions. However, this method is extremely new, and suffers several setbacks including: computational cost, a 
steep learning curve to implement, and the impact of light, shadow, and environmental surface conditions on results. Nevertheless, the study is promising for the future development of reliable methods of conducting artifact-level identification using aerial remote sensing instruments.

Another example of automated remote sensing analysis for the detection of ephemeral, complex, and degrading archaeological remains is the use of deep learning models to detect traces of sunken cart-tracks from the post-Medieval period in the Netherlands (Verschoof-van der Vaart and Landauer 2020). As the authors of this study note, archaeological research using deep learning (e.g., convolutional neural networks [CNNs]) and other automated approaches have done very little to investigate complex, large-scale landscape components (e.g., roadways). Using LiDAR data and a new deep learning model architecture, Verschoofvan der Vaart and Landauer (2020) manage to capture a broad network of roadways with promising levels of precision and accuracy. Nevertheless, issues of misclassification are pervasive, as these roadways are often damaged, overlaid with newer streets, and are, overall, much more difficult to discern from other, more pronounced features. The authors also point out that while model performance issues are present, the results of such automated analyses will permit for a more comprehensive understanding of transport networks in the post-Medieval period. Furthermore, it will improve chronological information pertaining to the connectivity of people and places throughout this landscape.

Researchers are also demonstrating how veryhigh-resolution satellite imagery can be used to record archaeological features typically overlooked by traditional landscape surveys (e.g., Klehm et al. 2019) or otherwise ephemeral archaeological deposits. Thabeng, Merlo, and Adam (2019) use WorldView-2 satellite imagery from Maxar (formerly DigitalGlobe) to locate dung deposits associated with archaeological farming communities in Botswana. Remains of animal stables within this region can be characterized by the presence of dung piles. The researchers use WorldView-2 - which has $1.84 \mathrm{~m}$ spatial resolution multispectral data and $0.46 \mathrm{~m}$ resolution panchromatic data - in conjunction with randomforest (RF) and support-vector machine (SVM) classifiers to successfully detect these dung piles. Overall, they achieve $\sim 95 \%$ accuracy and successfully reidentify $\sim 300$ archaeological sites, despite very few surface indicators of archaeological activities.

Thabeng and colleagues further explore the possibilities of detecting these ancient farming sites using hyperspectral analysis (Thabeng et al., 2020; Thabeng, Adam, \& Merlo, 2019). They find that collecting hyperspectral measurements of archaeological deposits on the ground can be used to train machine learning algorithms to directly detect these features in satellites, even those with coarser spatial resolutions (e.g., Sentinel-2, Landsat, etc.). While such feats require extensive fieldwork and laboratory analysis, it is extremely promising for the expansion of survey operations using automated procedures. Furthermore, the ability to detect subtle archaeological deposits in freely available satellite imagery is particularly significant for researchers without access to large pools of funding.

\section{PREDICTIVE MODELING AND THE INDIRECT DETECTION OF EPHEMERAL ARCHAEOLOGICAL DEPOSITS}

In this light, work recently conducted on Madagascar is demonstrating how freely available medium-resolution satellite imagery can be used to accurately predict the locations of ephemeral remnants of Holocene era foraging camps (Davis et al. 2020a). Using Sentinel-2 data - which is freely available from the European Space Agency - and SVM classifiers, the team identified culturally significant environmental resources across a $1400 \mathrm{~km}^{2}$ area of the island's southwest coast. Using these data, the researchers created a predictive model that operated under the theoretical assumptions of an ideal free distribution (IFD, Fretwell and Lucas 1969). IFD is a settlement model from population ecology that suggests populations - without any restrictions - will choose to settle areas with the best access to important natural resources. The results of this analysis successfully identified archaeological sites consisting of ephemeral artifact scatters with over $80 \%$ accuracy, while simultaneously adding to archaeological knowledge about the nature of settlement distributions in this region over the past several thousand years. Follow-up analyses further improved the model using spatial statistical modeling (Davis, DiNapoli and Douglass 2020).

While there are many instances of similar forms of predictive modeling in archaeology (e.g., Borie et al. 2019; Sonnemann et al. 2017), the explicit framing of the model in theoretical terms is significant for advancing archaeological remote sensing. Despite low data resolution and vegetative cover throughout much of the study region, Davis and colleagues (2020a) were able to reliably locate ephemeral archaeological deposits in record time compared with traditional ground-based survey approaches. Furthermore, the results of these projects led to the collection of enough training data to begin testing machine learning algorithms for the direct detection of these foraging sites (see Davis and Douglass In Review). The results of this continuing work are promising with accuracy metrics exceeding 90\% and providing archaeologists with the ability to quantify extant human niche construction and its ecological legacies.

\section{DETECTION OF EPHEMERAL SITES BY PROXY}

Apart from these examples, there are some researchers who have focused on the reconstruction 
of palaeoecological features (i.e., palaeorivers, lakes, streams, etc.), which in turn can help to pinpoint the locations of early archaeological sites. For example, researchers working in the Arabian Peninsula used a variety of hydrological algorithms and automation procedures to locate palaeohydrological features. Subsequently, these features acted as a proxy for Paleolithic archaeological sites, which successfully identified 19 new archaeological deposits (Breeze et al. 2015). Similarly, Elfadaly et al. (2020) used amplitude radar imagery to locate palaeorivers and drainage systems in the Mediterranean region, which in turn provides important insight to the placement of early Neolithic archaeological sites. While this study was not automated, it demonstrates the potential for using automated methods to locate non-archaeological features that act as proxies for early human settlements.

One of the most significant and widespread detection efforts by proxy involves vegetative signatures (e.g., Agapiou 2020; Bennett et al. 2012; Brooks and Johannes 1990; Lasaponara and Masini 2007). It has been well established that buried archaeological remains tend to affect plant health and growth patterns, and in some instances even change the kinds of plants that occupy areas with associated cultural contexts (Brophy and Cowley 2005; Verhoeven 2012; Wilson 1975). With the advent of mathematical metrics of quantifying vegetation, the use of vegetative indices for archaeological prospection efforts has been a staple of semi-automated analyses for decades (see Bennett et al. 2012). Indeed, such vegetative proxies have been incorporated into many predictive modeling efforts to locate archaeological sites (e.g., Agapiou 2020; Calleja et al. 2018; Davis et al. 2020a; Hegyi et al. 2020; Kirk, Thompson and Lippitt 2016; Yaworsky and Codding 2018). In several instances, vegetative indices have been used in conjunction with other automated remote sensing methods (e.g., Davis et al. 2020a; Kirk, Thompson and Lippitt 2016; Yaworsky et al. 2020).

Despite the successes of studies like those discussed in this section, the vast majority of automation within archaeological remote sensing continues to utilize the most novel methodologies (e.g., machine learning and deep learning) but focus on the same types of large, topographically distinct archaeological objects (e.g., Orengo et al. 2020; Sărăşan et al. 2020; Somrak, Džeroski and Kokalj 2020; Soroush et al. 2020; Trier, Reksten and Løseth 2021). These efforts are important and worthwhile, but so too is broadening the range of questions that can be assessed by such techniques. Using remotely sensed data as proxies for archaeological prospection can aid researchers not only in locating ephemeral archaeological traces (Figure 2), but also in linking these studies back to broader archaeological research questions. The concept of archaeological landscapes as a palimpsest (as illustrated in Figure 2) is a fundamental tenet in the development of landscape archaeology as a holistic archaeological discipline. In this context, remote sensing approaches, in combination with other datasets from geology, demography, history, and anthropology provide long-term observations of both visible and ephemeral anthropogenic features.

\section{THE CASE FOR THEORETICAL INTEGRATION AND EXPANSION WITHIN AUTOMATED REMOTE SENSING ANALYSIS}

As the previous section highlights, automated remote sensing analyses are beginning to make breakthroughs in documenting subtle traces of the archaeological record that are often overlooked in landscape-scale research. This, in turn, can help to advance archaeological theory, but all too often direct linkages to theoretical frameworks are absent from automated remote sensing approaches (Davis and Douglass 2020; Thompson et al. 2011). When the data used is of high enough resolution it is tempting to simply detect whatever objects can be found, irrespective of broader archaeological frameworks. However, when data is too coarse for such "direct" detection approaches, or the procurement of an unbounded dataset is too costly, theory is invaluable for framing methods of analysis (e.g., Davis et al. 2020a).

Indeed, the detection of ephemeral archaeological sites has been aided by predictive modeling efforts based on environmental information procured from mediumto-coarse-grained satellite imagery. For example, Custer et al. (1986) use Landsat satellite imagery and statistical machine learning to classify environmental landscape types to determine the greatest likelihood for archaeological site locations. While this method is most explicitly rooted in statistical theory, the predictive modeling approach itself is entrenched in cultural ecology approaches that have been part of standard archaeological frameworks for nearly a century (Butzer 1982; Steward 1937, 1955). Very similar approaches persist in archaeology today, many of which rely on at least some remotely sensed environmental information (e.g., Davis, DiNapoli and Douglass 2020; Verhagen and Whitley 2012; Yaworsky et al. 2020).

Perhaps the greatest theoretical advancement offered by the methods discussed here is the reformulation of "site"-based archaeological studies. For decades, researchers have challenged the usefulness of the archaeological unit of "site" and its role in archaeological investigations (Caraher, Nakassis and Pettegrew 2006; Dunnell 1992; Dunnell and Dancey 1983; McCoy 2020). Particularly with the rise of geospatial technologies like remote sensing, the "site" concept has been vastly complicated by new levels of resolution and scale (McCoy 2020: S24; also see Czajlik et al. 2021). Alternatives 


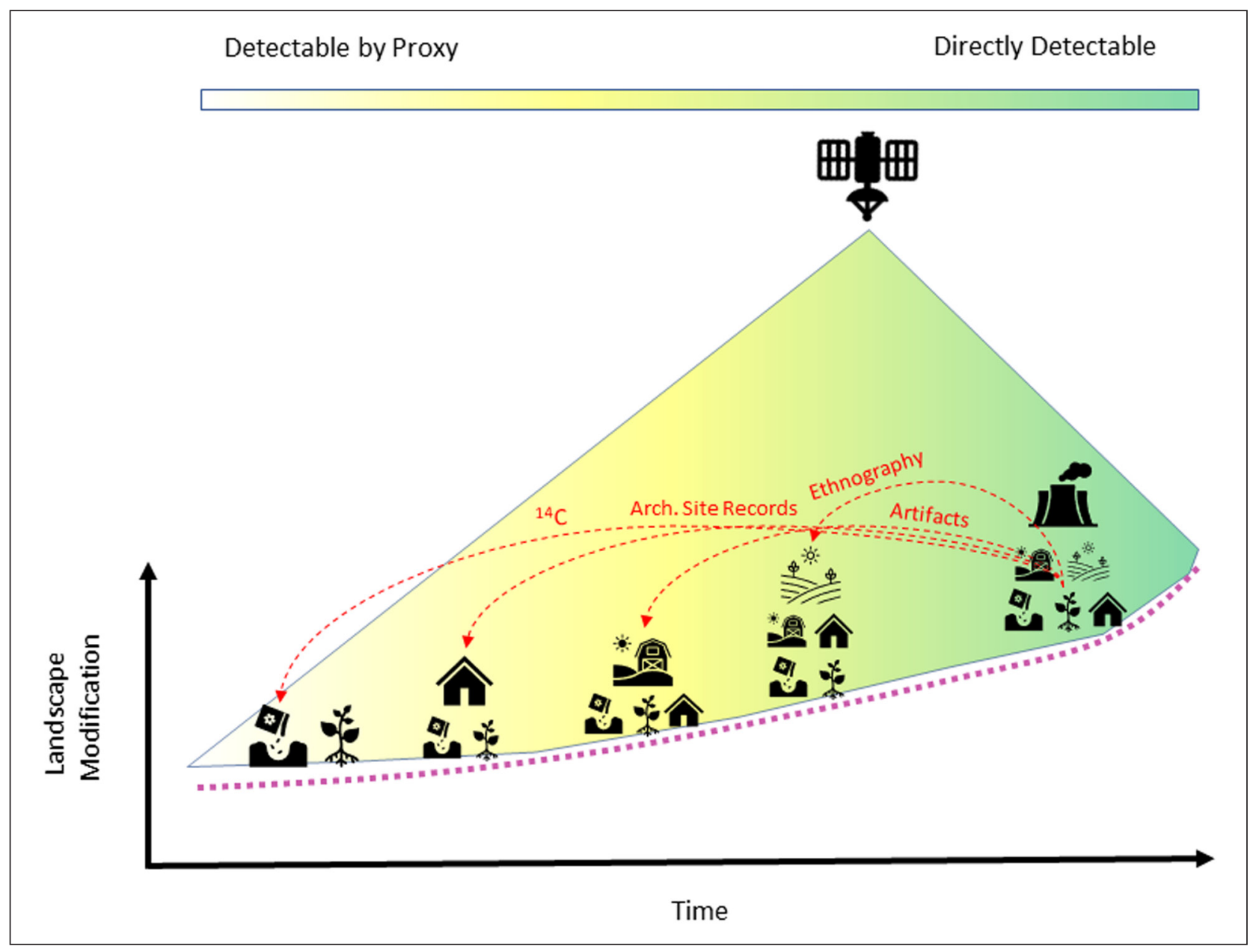

Figure 2 Over time, the degree of landscape modification has increased (purple dotted-line). The modern landscape, which is directly detectable (highlighted in green) by satellite remote sensing, represents a palimpsest of collective human actions, which are each detectable in different ways and to varying degrees. Modern modifications and some older landscape modifications can be directly identified, while other older and subtler activities that leave fewer direct traces can be identified by proxy (highlighted in yellow), wherein we can infer the timing of different changes seen in the present by linking visible differences to known areas of historic/archaeological human presence (red dashed-arrows).

to "site" based investigation have been proposed and include "siteless" surveys (Dunnell and Dancey 1983), landscape surveys, which, rather than assess the archaeological record as a collection of individual "sites", views it as a connected system of different parts (Anschuetz, Wilhusen and Scheick 2001), and in temporal terms (coined time perspectivism [Bailey 1981, 2008]), which view the archaeological record as a palimpsest without dissected components. With an ability to record archaeological components at multiple scales and at varying levels of resolution, how we think about and categorize archaeological data requires reformulation. As researchers have argued, it is vital that the term "site" is understood as a result of archaeological observation, and not anything inherent in how things actually are; in other words, we find sites, but sites are not what we actively seek out (Dunnell 1992; McCoy 2020).

As remote sensing studies shift towards documentation of artifacts and anthropogenic niche construction at finer scales, the very nature of remotely detected archaeological data will require adjustment, as "sites" are no longer an adequate descriptor of the results of these investigations. Rather, remote sensing archaeology can record - to varying degrees of completeness - the very palimpsests and interconnected systems that define the record according to landscape and time perspectivist approaches. Take, for example, recent work utilizing multitemporal image analysis (e.g., Lasaponara, Abate and Masini 2021; Orengo et al. 2020) which takes time-series averages of remote sensing imagery to establish atemporal geophysical profiles of features of interest. In this case, a large portion of time is used to establish a general set of characteristics by which archaeological and anthropogenic activities exist relative to other elements within that geographic space (like a time perspectivist approach [sensu Bailey 1981]). Similarly, landscape theoretical perspectives are encapsulated by remote sensing instruments whereby individual features and "sites" are defined in terms of their similarity or difference from surrounding regions based on spectral signature, physical or chemical composition, or orientation within a landscape of connected features. 
Another important contribution of automated remote sensing techniques is the capability of characterizing the archaeological record in a uniform and semantically consistent manner (Davis 2020), alleviating one of the major problems with the "site" concept. As McCoy (2020) argues, remotely sensed archaeological data may require new and distinct definitions from traditional "site" based categories. At the same time, it is important not to distance remotely sensed and ground-based data as fundamentally different or incompatible with one another, as this deepens an epistemological divide among researchers with respect to the connection of different data sources to their human roots (Hacıgüzeller 2012; Millican 2012; Thomas 1993).

While not all scholars will agree on the best theoretical approach, remote sensing data can be incorporated into many studies rooted in very different theoretical positions. For example, researchers have used remotely sensed data to assess social questions concerning changes in landscape use (e.g., Chase, Chase and Chase 2017; Inomata et al. 2018; Vining 2018), mobility and connectivity (e.g., Oltean and Fonte 2021; Pawlowicz 2020), socio-political boundaries (e.g., Evans et al. 2013; Harrower and D’Andrea 2014; Inomata et al. 2020), and perceptions and experiences of place (e.g., Fitzjohn 2007; Millican 2012), among others. While not all these approaches necessarily rely on (or require) automated remote sensing analysis, many - if not all - of these questions can benefit from automated remote sensing studies - specifically in the use of data generated by such endeavors. For example, Cerrillo-Cuenca and BuenoRamírez (2019) use data collected via automated remote sensing analysis by Cerrillo-Cuenca (2017) to explore the differences in land-use and monument distribution in the Iberian Peninsula. This study revealed new connections between different kinds of archaeological features, indicating a vast landscape of human activity - even in so-called "marginal" locations where prior research had discovered very few archaeological materials. While this example focuses on monumental sites, the same can be shown in cases of ephemeral archaeological patterns discussed above.

In addition to the interpretive advantages of theoretical integration, the incorporation of archaeological theory into automated research can also help alleviate the problem posed by taphonomic processes mentioned earlier. By formalizing our expectations of what modifications to cultural materials may have taken place using ontological systems (see Arvor et al. 2019; Magnini and Bettineschi 2019), we can improve our capacity to predict and identify these features within the modern landscape, as it widens our expectations of the form that these materials may take given changes over time.

Such evolutionary perspectives of the archaeological record are well established, and in relating such theoretical knowledge directly into automated remote sensing analysis, we can improve the utility of these approaches, as well as their overall impact on archaeological thought. For example, niche construction theory (NCT) - a branch of evolutionary biology - postulates that ecological modifications made by individual organisms result in subsequent environmental changes that impact other cohabitating organisms (Laland and O'Brien 2010; Odling-Smee, Laland and Feldman 2003). The line of thought associated with NCT goes well with Magnini and Bettineschi's (2019) concept of DhSMs discussed previously, as the assumptions of NCT can create hypotheses surrounding the long-term ecological effects of human activity. This, in turn, can inform researchers of possible proxies by which archaeological materials can be identified. In practice, new research is already demonstrating the potential of such an approach for documenting ephemeral foraging sites via satellite remote sensing (Davis and Douglass In Review; also see Vining 2018; Czajlik et al. 2021).

While I advocate for the linkage of archaeological remote sensing with explicit archaeological theory, it is obvious that such a methodological-theoretical marriage is not always warranted depending upon one's research goals. All research is based on some set of theoretical assumptions, and automated remote sensing is no exception: it is tightly intertwined in information theory, statistical and mathematical theory, and geophysical theory, among others. However, the issue that arises when archaeological theory is left out is the delegation of all such methodological achievements as simply a technical report within archaeological literature.

According to a Web of Science search (see Supplemental Materials), automated archaeology research is primarily cited by articles in geoscience and remote sensing journals, followed by interdisciplinary publications and archaeological science publications (Figure 3). Medical journals, such as Statistics in Medicine and International Journal of Environmental Research and Public Health were unexpected sources of citations, and such publications appear primarily concerned with spatial modeling of disease transmission. Further work would be needed to evaluate these trends fully, but this goes beyond the scope of this article.

When evaluating the publications that reference automated remote sensing studies (see Supplementary Materials for more details), the bulk of these citations appear to be methodologically focused where direct contributions to archaeological theoretical questions are of secondary importance, if mentioned at all (Supplementary Materials; Table S1). While many methodological studies are small parts of much larger projects, in such cases, the results of these studies should be used and cited within papers that result from these larger research agendas. However, it appears that such advances are primarily published as methods reports, and are thereafter cited primarily by other methods reports, 


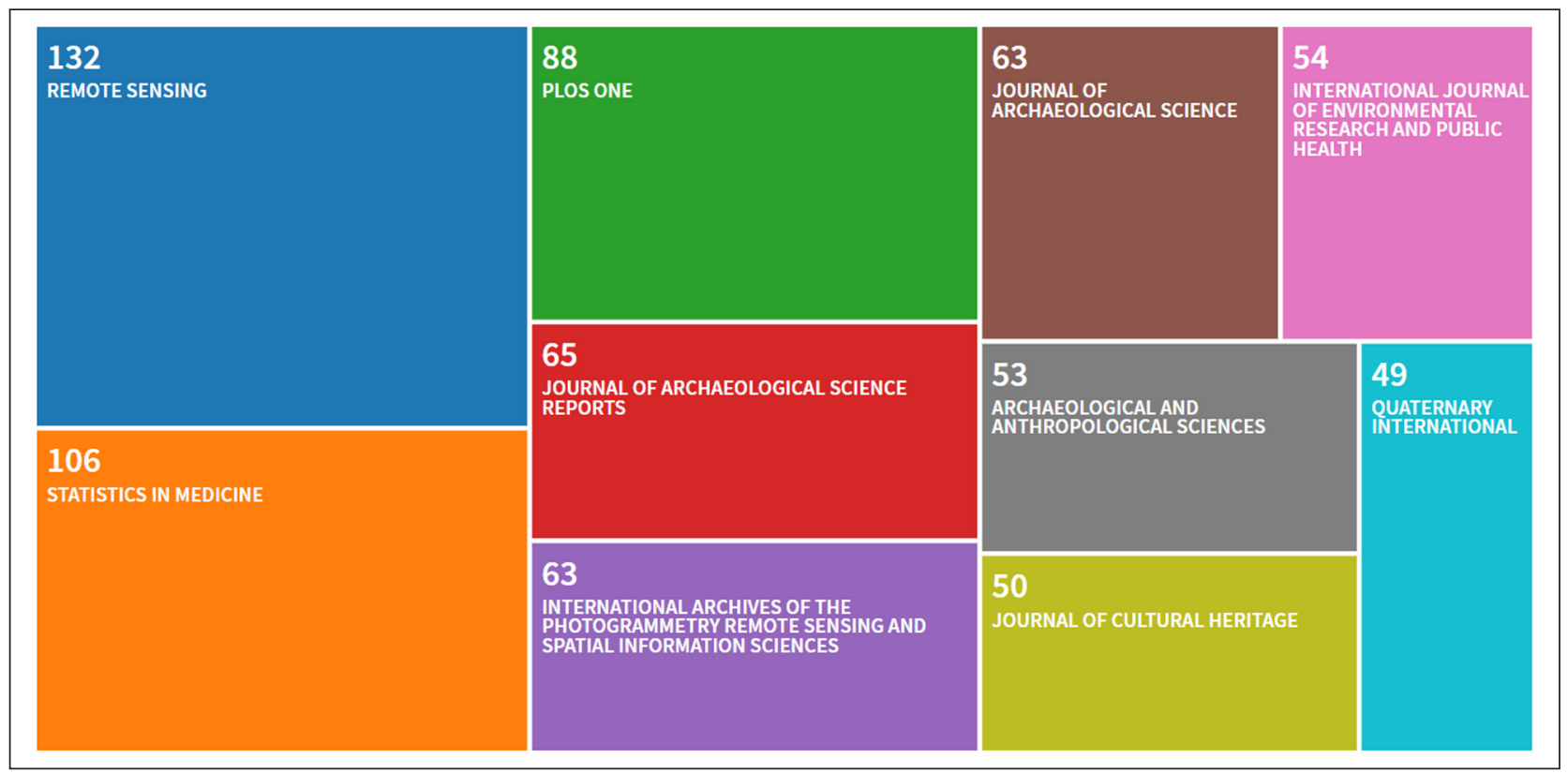

Figure 3 Top 10 publications of articles that cite automated remote sensing archaeology papers (Results from Web of Science search conducted on 2 March 2021).

but rarely by scholars delving into more theoretical research. As such, the abundance of data generated by automated remote sensing archaeologists may never find its way into larger-scale investigations that are the crux of archaeological inquiry. Thus, it is imperative that datasets procured by such work be incorporated into broader, interdisciplinary studies of the archaeological record; and doing so requires an engagement with theoretical frameworks from the social sciences (i.e., anthropology, archaeology, geography, etc.).

\section{SUMMARY}

Automated archaeological remote sensing has made incredible strides in the development of algorithms to locate a myriad of feature types from image datasets. The achievements of locating large architectural features can make further advances in archaeological research by helping to locate more ephemeral traces of human activity. In many cases, the detection of monumental structures (or other topographically distinct cultural heritage) can actually lead researchers to discover ephemeral cultural remains (e.g., Davis, Seeber and Sanger 2020; Klehm et al. 2019). The use of larger-scale cultural heritage as a proxy for detecting smaller scale heritage is certainly worthy of further emphasis in future studies. As the above discussion illustrates, researchers are beginning to make great strides in advancing the use of automated remote sensing methods for the documentation of the most difficult components of the archaeological record to identify.

Ultimately, the future of AI, machine learning, and other automation techniques within remote sensing archaeology is contingent upon what it can offer the discipline beyond data collection. Practitioners of this methodological niche must demonstrate the benefits that such approaches offer to the study and interpretation of the archaeological record, in addition to its documentation power. For example, automated methods can help redefine how archaeologists classify the materials we study. Instead of relying on "site-based" analyses, remote sensing data can be used to better account for multiple scales of anthropogenic activity that push beyond the bounds of "sites" or "features", but rather encompass a myriad of deposits including microscale artifact scatters, landscape-level transformations, and multi-temporal anthropogenic modifications that define human activity in a region.

With the ability of computer automation to consistently define units of measurement, these methods can also more concretely define the boundaries of "landscape" archaeology, as opposed to other forms of settlement studies. Kowalewski (2008) criticizes many "landscape" scale approaches to archaeology for their lack of unified organization, serving more as an "umbrella" or "junk-drawer" where virtually everything can be included. He argues that settlement patterns must be viewed as a living system that is bounded by specified scales within a particular place (Kowalewski 2008). Automation may hold a solution to this critique. By standardizing units of measurement and means of archaeological identification, semantic consistency can aid in the explicit defining of landscape boundaries and characteristics, making "landscape" approaches less of a hodgepodge and more explicit in their theoretical assumptions. Furthermore, archaeological research can be replicated by different scholars at multiple scales of analysis because of such standardization. Not only does this improve archaeological research in terms of 


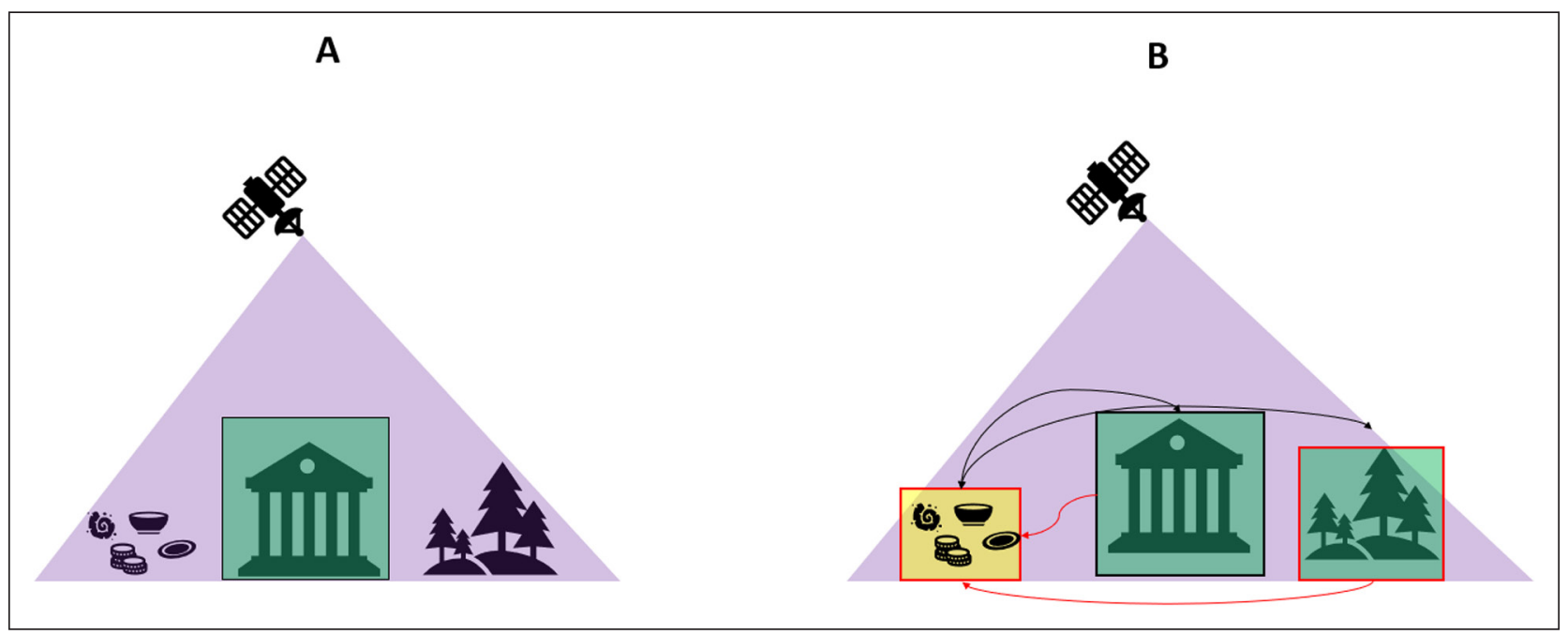

Figure 4 A: Remote sensing usually scans entire regions (purple), but traditional uses of automation in archaeology focus only on directly identifying (green box) large-scale, topographically distinct features. B: Shows proposed integrative automated archaeological remote sensing, wherein monuments are still detected, but so too are other environmental features which can be used as proxies (boxes with red outlines) to detect small artifact scatters and non-architectural components of the archaeological record (yellow box). Detections should then form a feedback loop wherein the large- and small-scale features inform archaeologists about each other as parts of a complete system.

study design and reliability of results, but it can also aid in solving the problem of taphonomy, and how we approach components of the archaeological record that have been changed over the course of time.

Nonetheless, publications focused on the development of automated protocols often focus on the methods themselves and offer little concrete discussion of the implications that the method has for understanding important archaeological phenomena (cf., Cerrillo-Cuenca and Bueno-Ramírez 2019; Davis et al. 2020b; Freeland et al. 2016; Klehm et al. 2019). While methods reports are invaluable for advancing the utility of automated procedures, great progress has been made in recent years leading to highly accurate protocols. While improvements can always be made, it is time for the methodological rigor afforded by automation to be applied to a wider set of phenomena than mounds and other large-scale cultural features (Figure 4). By integrating automated methods for the study of anthropogenic landscapes as a whole, we can advance our understanding of the archaeological record in a more complete manner by viewing the record as a system of interrelated components that provide information at different scales.

In sum, achievements made by those working on methodologically innovative research like automation should pass beyond methodological significance by directly informing larger research agendas (Figure 1). Thus, the advocation of automated remote sensing to push the boundaries towards ephemeral archaeological deposits is an extension of this argument: by extending the utility of these innovative data collection solutions, this "niche" of archaeological research can begin to impact the discipline's most central questions and longstanding debates by documenting the presence and impact of underrepresented components of the archaeological record.

\section{ADDITIONAL FILE}

The additional file for this article can be found as follows:

- Supplementary Materials. Bibliographic Analysis in Web of Science. DOI: https://doi.org/10.5334/jcaa.72.s1

\section{ACKNOWLEDGEMENTS}

I thank the two anonymous reviewers for their helpful comments which led to an improvement of the manuscript.

\section{FUNDING INFORMATION}

No specific funding was acquired for this study. Article processing fee supported by the Department of Anthropology at Penn State.

\section{COMPETING INTERESTS}

The author has no competing interests to declare.

\section{AUTHOR AFFILIATION}

Dylan Davis (D) orcid.org/0000-0002-5783-3578

The Pennsylvania State University, US 


\section{REFERENCES}

Abate, N, Elfadaly, A, Masini, N and Lasaponara, R. 2020. Multitemporal 2016-2018 Sentinel-2 Data Enhancement for Landscape Archaeology: The Case Study of the Foggia Province, Southern Italy. Remote Sensing, 12(8): 1309. DOI: https://doi.org/10.3390/rs12081309

Adamopoulos, E and Rinaudo, F. 2020. UAS-Based Archaeological Remote Sensing: Review, Meta-Analysis and State-of-the-Art. Drones, 4(3): 46. DOI: https://doi. org/10.3390/drones4030046

Agapiou, A. 2020. Optimal Spatial Resolution for the Detection and Discrimination of Archaeological Proxies in Areas with Spectral Heterogeneity. Remote Sensing, 12(1): 136. DOI: https://doi.org/10.3390/rs12010136

Anschuetz, KF, Wilhusen, RH and Scheick, CL. 2001. An Archaeology of Landscapes: Perspectives and Directions. Journal of Archaeological Research, 9(2): 157-211. DOI: https://doi.org/10.1023/A:1016621326415

Arvor, D, Belgiu, M, Falomir, Z, Mougenot, I and Durieux, L. 2019. Ontologies to interpret remote sensing images: why do we need them? GIScience \& Remote Sensing, 1-29. DOI: https://doi.org/10.1080/15481603.2019.1587890

Bailey, G. 1981. Concepts, time-scales and explanations in economic prehistory. Economic archaeology, 96: 97-117.

Bailey, G. 2008. Time perspectivism: origins and consequences. In: Holdaway, $\mathrm{S}$ and Wandsnider, $\mathrm{L}$ (eds.), Time in Archaeology: Time Perspectivism Revisited, 13-30. Salt Lake City: University of Utah Press.

Bennett, R, Welham, K, Hill, RA and Ford, ALJ. 2012. The Application of Vegetation Indices for the Prospection of Archaeological Features in Grass-dominated Environments. Archaeological Prospection, 19(3): 209-218. DOI: https://doi org/10.1002/arp.1429

Bescoby, DJ. 2006. Detecting Roman land boundaries in aerial photographs using Radon transforms. Journal of Archaeological Science, 33(5): 735-743. DOI: https://doi. org/10.1016/j.jas.2005.10.012

Bonhage, A, Eltaher, M, Raab, T, Breuß, M, Raab, A and Schneider, A. 2021. A modified Mask region-based convolutional neural network approach for the automated detection of archaeological sites on high-resolution light detection and ranging-derived digital elevation models in the North German Lowland. Archaeological Prospection, 2021: 1-10. DOI: https://doi.org/10.1002/arp.1806

Borie, C, Parcero-Oubiña, C, Kwon, Y, Salazar, D, Flores, C, Olguín, L and Andrade, P. 2019. Beyond Site Detection: The Role of Satellite Remote Sensing in Analysing Archaeological Problems. A Case Study in Lithic Resource Procurement in the Atacama Desert, Northern Chile. Remote Sensing, 11(7): 869. DOI: https://doi.org/10.3390/ rs11070869

Breeze, PS, Drake, NA, Groucutt, HS, Parton, A, Jennings, RP, White, TS, Clark-Balzan, L, Shipton, C, Scerri, EML, Stimpson, CM, Crassard, R, Hilbert, Y, Alsharekh, A, Al-Omari, A and Petraglia, MD. 2015. Remote sensing and
GIS techniques for reconstructing Arabian palaeohydrology and identifying archaeological sites. Quaternary International, 382: 98-119. DOI: https://doi.org/10.1016/j. quaint.2015.01.022

Brooks, RR and Johannes, D. 1990. Phytoarchaeology. Portland, OR: Dioscorides Press.

Brophy, K and Cowley, D. 2005. From the air: understanding aerial archaeology. Stroud: Tempus.

Butzer, KW. 1982. Archaeology as Human Ecology: Method and Theory for a Contextual Approach. Cambridge: Cambridge University Press. DOI: https://doi.org/10.1017/ CB09780511558245

Calleja, JF, Requejo Pagés, O, Díaz-Álvarez, N, Peón, J, Gutiérrez, N, Martín-Hernández, E, Cebada Relea, A, Rubio Melendi, D and Fernández Álvarez, P. 2018. Detection of buried archaeological remains with the combined use of satellite multispectral data and UAV data. International Journal of Applied Earth Observation and Geoinformation, 73: 555-573. DOI: https://doi.org/10.1016/j.jag.2018.07.023

Caraher, WR, Nakassis, D and Pettegrew, DK. 2006. Siteless Survey and Intensive Data Collection in an Artifact-rich Environment: Case Studies from the Eastern Corinthia, Greece. Journal of Mediterranean Archaeology, 19(1): 7-43. DOI: https://doi.org/10.1558/jmea.2006.19.1.7

Casana, J. 2014. Regional-Scale Archaeological Remote Sensing in the Age of Big Data. Advances in Archaeological Practice, 2(03): 222-233. DOI: https://doi.org/10.7183/23263768.2.3.222

Caspari, G and Crespo, P. 2019. Convolutional neural networks for archaeological site detection - Finding "princely" tombs. Journal of Archaeological Science, 110: 104998. DOI: https:// doi.org/10.1016/j.jas.2019.104998

Cerrillo-Cuenca, E. 2017. An approach to the automatic surveying of prehistoric barrows through LiDAR. Quaternary International, 435: 135-145. DOI: https://doi.org/10.1016/j. quaint.2015.12.099

Cerrillo-Cuenca, E and Bueno-Ramírez, P. 2019. Counting with the invisible record? The role of LiDAR in the interpretation of megalithic landscapes in south-western Iberia (Extremadura, Alentejo and Beira Baixa). Archaeological Prospection, 1-14. DOI: https://doi.org/10.1002/arp.1738

Chase, ASZ, Chase, DZ and Chase, AF. 2017. LiDAR for Archaeological Research and the Study of Historical Landscapes. In: Masini, N and Soldovieri, F (eds.), Sensing the Past, 89-100. Cham: Springer International Publishing. DOI: https://doi.org/10.1007/978-3-319-50518-3_4

Custer, JF, Eveleigh, T, Klemas, V and Wells, I. 1986. Application of Landsat Data and Synoptic Remote Sensing to Predictive Models for Prehistoric Archaeological Sites: An Example from the Delaware Coastal Plain. American Antiquity, 51(03): 572-588. DOI: https://doi. org/10.2307/281753

Czajlik, Z, Árvai, M, Mészáros, J, Nagy, B, Rupnik, L and Pásztor, L. 2021. Cropmarks in Aerial Archaeology: New Lessons from an Old Story. Remote Sensing, 13(6): 1126. DOI: https://doi.org/10.3390/rs13061126 
Davis, DS. 2019. Object-based image analysis: a review of developments and future directions of automated feature detection in landscape archaeology. Archaeological Prospection, 26(2): 155-163. DOI: https://doi.org/10.1002/ arp. 1730

Davis, DS. 2020. Defining what we study: The contribution of machine automation in archaeological research. Digital Applications in Archaeology and Cultural Heritage, 18: e00152. DOI: https://doi.org/10.1016/j.daach.2020.e00152

Davis, DS, Andriankaja, V, Carnat, TL, Chrisostome, ZM, Colombe, C, Fenomanana, F, Hubertine, L, Justome, R, Lahiniriko, F, Léonce, H, Manahira, G, Pierre, BV, Roi, R, Soafiavy, P, Victorian, F, Voahirana, V, Manjakahery, B and Douglass, K. 2020a. Satellite-based remote sensing rapidly reveals extensive record of Holocene coastal settlement on Madagascar. Journal of Archaeological Science, 115: 105097. DOI: https://doi.org/10.1016/j. jas.2020.105097

Davis, DS, DiNapoli, RJ and Douglass, K. 2020. Integrating point process models, evolutionary ecology, and traditional knowledge improves landscape archaeology: A case from Southwest Madagascar. Geosciences, 10(8): 267. DOI: https://doi.org/10.3390/geosciences10080287

Davis, DS, DiNapoli, RJ, Sanger, MC and Lipo, CP. 2020b. The integration of lidar and legacy datasets provides improved explanations for the spatial patterning of shell rings in the American Southeast. Advances in Archaeological Practice, 8(4): 361-375. DOI: https://doi.org/10.1017/aap.2020.18

Davis, DS and Douglass, K. 2020. Aerial and Spaceborne Remote Sensing in African Archaeology: A Review of Current Research and Potential Future Avenues. African Archaeological Review, 37(1): 9-24. DOI: https://doi. org/10.1007/s10437-020-09373-y

Davis, DS and Douglass, K. In Review. Remote Sensing Reveals Lasting Legacies of Land-Use by Small-Scale Communities in the southwestern Indian Ocean. Frontiers in Ecology and Evolution.

Davis, DS, Sanger, MC and Lipo, CP. 2019. Automated mound detection using lidar and object-based image analysis in Beaufort County, South Carolina. Southeastern Archaeology, 38(1): 23-37. DOI: https://doi.org/10.1080/073457 $8 X .2018 .1482186$

Davis, DS, Seeber, KE and Sanger, MC. 2020. Addressing the problem of disappearing cultural landscapes in archaeological research using multi-scalar survey. The Journal of Island and Coastal Archaeology. DOI: https://doi. org/10.1080/15564894.2020.1803457

De Laet, V, Paulissen, E and Waelkens, M. 2007. Methods for the extraction of archaeological features from very high-resolution Ikonos-2 remote sensing imagery, Hisar (southwest Turkey). Journal of Archaeological Science, 34(5): 830-841. DOI: https://doi.org/10.1016/j. jas.2006.09.013

Doneus, M. 2013. Die hinterlassene Landschaft - Prospektion und Interpretation in der Landschaftsarchäologie. Vienna:
Verlag der Österreichischen Akademie der Wissenschaften. DOI: https://doi.org/10.2307/j.ctt1vw0qcb

Drager, DL. 1983. Projecting archaeological site concentrations in the San Juan Basin, New Mexico. In: Drager, DL and Lyons, TR (eds.), Remote Sensing in Cultural Resource Management, 151-157. Washington, DC: National Park Service.

Dunnell, RC. 1992. The Notion Site. In: Rossignol, J and Wandsnider, L (eds.), Space, Time, and Archaeological Landscapes, 21-41. Boston, MA: Springer US. DOI: https:// doi.org/10.1007/978-1-4899-2450-6_2

Dunnell, RC and Dancey, WS. 1983. The Siteless Survey: A Regional Scale Data Collection Strategy. Advances in Archaeological Method and Theory, 6: 267-287. DOI: https:// doi.org/10.1016/B978-0-12-003106-1.50012-2

Elfadaly, A, Abate, N, Masini, N and Lasaponara, R. 2020. SAR Sentinel 1 Imaging and Detection of Palaeo-Landscape Features in the Mediterranean Area. Remote Sensing, 12(16): 2611. DOI: https://doi.org/10.3390/rs12162611

Evans, DH, Fletcher, RJ, Pottier, C, Chevance, J-B, Soutif, D, Tan, BS, Im, S, Ea, D, Tin, T, Kim, S, Cromarty, C, De Greef, S, Hanus, K, Baty, P, Kuszinger, R, Shimoda, I and Boornazian, G. 2013. Uncovering archaeological landscapes at Angkor using lidar. Proceedings of the National Academy of Sciences, 110(31): 12595-12600. DOI: https://doi.org/10.1073/pnas.1306539110

Findlow, FJ and Confeld, L. 1980. LANDSAT imagery and the analysis of archaeological catchment territories: a test of the method. Anthropology, 10: 31-52.

Fitzjohn, M. 2007. Viewing places: GIS applications for examining the perception of space in the mountains of Sicily. World Archaeology, 39(1): 36-50. DOI: https://doi. org/10.1080/00438240601136439

Freeland, T, Heung, B, Burley, DV, Clark, G and Knudby, A. 2016. Automated feature extraction for prospection and analysis of monumental earthworks from aerial LiDAR in the Kingdom of Tonga. Journal of Archaeological Science, 69: 64-74. DOI: https://doi.org/10.1016/j.jas.2016.04.011

Fretwell, SD and Lucas, HL. 1969. On territorial behavior and other factors influencing habitat distribution in birds: I. Theoretical development. Acta Biotheoretica, 19(1): 16-36. DOI: $h$ ttps://doi.org/10.1007/BF01601953

Garcia-Molsosa, A, Orengo, HA, Lawrence, D, Philip, G, Hopper, K and Petrie, CA. 2021. Potential of deep learning segmentation for the extraction of archaeological features from historical map series. Archaeological Prospection, 2021: 1-13. DOI: https://doi.org/10.1002/arp.1807

Guarino, N, Oberle, D and Staab, S. 2009. What is an ontology? In: Staab, S and Studer, R (eds.), Handbook on ontologies, 1-17. Berlin, Heidelberg: Springer. DOI: https://doi. org/10.1007/978-3-540-92673-3_0

Guyot, A, Hubert-Moy, L and Lorho, T. 2018. Detecting Neolithic Burial Mounds from LiDAR-Derived Elevation Data Using a Multi-Scale Approach and Machine Learning Techniques. Remote Sensing, 10(2): 225. DOI: https://doi. org/10.3390/rs10020225 
Hacıgüzeller, P. 2012. GIS, critique, representation and beyond Journal of Social Archaeology, 12(2): 245-263. DOI: https:// doi.org/10.1177/1469605312439139

Hanson, WS. 2010. The future of aerial archaeology in Europe, Photo Interprétation. European Journal of Applied Remote Sensing, 46(1): 3-11.

Harrower, MJ and D'Andrea, AC. 2014. Landscapes of State Formation: Geospatial Analysis of Aksumite Settlement Patterns (Ethiopia). African Archaeological Review, 31(3): 513-541. DOI: https://doi.org/10.1007/s10437-014-9165-4

Hegyi, A, Sarris, A, Curta, F, Floca, C, Forțiu, S, Urdea, P, Onaca, A, Timofte, F, Pisz, M, Timut, S, Nica, M, Maciulschi, D and Stavilă, A. 2020. Deserted Medieval Village Reconstruction Using Applied Geosciences. Remote Sensing, 12(12): 1975. DOI: https://doi.org/10.3390/rs12121975

Howey, MCL, Sullivan, FB, Burg, MB and Palace, MW. 2020. Remotely Sensed Big Data and Iterative Approaches to Cultural Feature Detection and Past Landscape Process Analysis. Journal of Field Archaeology, 45(sup1): S27-S38. DOI: https://doi.org/10.1080/00934690.2020.1713435

Inomata, T, Triadan, D, Pinzón, F, Burham, M, Ranchos, JL, Aoyama, K and Haraguchi, T. 2018. Archaeological application of airborne LiDAR to examine social changes in the Ceibal region of the Maya lowlands. In: Hart, JP (ed.), PLOS ONE, 13(2): e0191619. DOI: https://doi.org/10.1371/ journal.pone.0191619

Inomata, T, Triadan, D, Vázquez López, VA, Fernandez-Diaz, JC, Omori, T, Méndez Bauer, MB, García Hernández, M, Beach, T, Cagnato, C, Aoyama, K and Nasu, H. 2020. Monumental architecture at Aguada Fénix and the rise of Maya civilization. Nature. DOI: https://doi.org/10.1038/ s41586-020-2343-4

Jahjah, M, Ulivieri, C, Invernizzi, A and Parapetti, R. 2007. Archaeological remote sensing application pre-post war situation of Babylon archaeological site-Iraq. Acta Astronautica, 61(1-6): 121-130. DOI: https://doi. org/10.1016/j.actaastro.2007.01.034

Jones, RJA. 1979. Crop marks induced by soil moisture stress at an iron age site in Midland England, UK. In: Proceedings of the 18th international symposium on archaeometry and archaeological prospection, Bonn, 14-17 March 1978, 656-668.

Kirk, SD, Thompson, AE and Lippitt, CD. 2016. Predictive Modeling for Site Detection Using Remotely Sensed Phenological Data. Advances in Archaeological Practice, 4(1): 87-101. DOI: https://doi.org/10.7183/23263768.4.1.87

Klehm, C, Barnes, A, Follett, F, Simon, K, Kiahtipes, C and Mothulatshipi, S. 2019. Toward archaeological predictive modeling in the Bosutswe region of Botswana: Utilizing multispectral satellite imagery to conceptualize ancient landscapes. Journal of Anthropological Archaeology, 54: 68-83. DOI: https://doi.org/10.1016/j.jaa.2019.02.002

Kowalewski, SA. 2008. Regional Settlement Pattern Studies. Journal of Archaeological Research, 16(3): 225-285. DOI: https://doi.org/10.1007/s10814-008-9020-8
Laland, KN and O'Brien, MJ. 2010. Niche Construction Theory and Archaeology. Journal of Archaeological Method and Theory, 17(4): 303-322. DOI: https://doi.org/10.1007/ s10816-010-9096-6

Lambers, K. 2018. Airborne and Spaceborne Remote Sensing and Digital Image Analysis in Archaeology. In: Siart, C, Forbriger, M and Bubenzer, O (eds.), Digital Geoarchaeology, 109-122. Cham: Springer International Publishing. DOI: https://doi.org/10.1007/978-3-319-25316-9_7

Lambers, $\mathbf{K}$ and Traviglia, A. 2016. Automated detection in remote sensing archaeology: a reading list. AARGnews, 53 : 25-29.

Lambers, K, Verschoof-van der Vaart, W and Bourgeois, Q. 2019. Integrating Remote Sensing, Machine Learning, and Citizen Science in Dutch Archaeological Prospection. Remote Sensing, 11(7): 794. DOI: https://doi.org/10.3390/ rs11070794

Lasaponara, R, Abate, $\mathbf{N}$ and Masini, N. 2021. On the Use of Google Earth Engine and Sentinel Data to Detect "Lost" Sections of Ancient Roads. The Case of Via Appia. IEEE Geoscience and Remote Sensing Letters, 1-5. DOI: https:// doi.org/10.1109/LGRS.2021.3054168

Lasaponara, $\mathbf{R}$ and Masini, N. 2007. Detection of archaeological crop marks by using satellite QuickBird multispectral imagery. Journal of Archaeological Science, 34(2): 214-221. DOI: https://doi.org/10.1016/j. jas.2006.04.014

Lemmens, JPM, Stančić, Z and Verwaal, R. 1993. Automated archaeological feature extraction from digital aerial photographs. In: Andresen, J, Madsen, T and Scollar, I (eds.), CAA92-Computing the Past: Computer Applications and Quantitative Methods in Archaeology, 45-51. Aarhus: Aarhus University Press.

Luo, L, Wang, X, Guo, H, Lasaponara, R, Zong, X, Masini, N, Wang, G, Shi, P, Khatteli, H, Chen, F, Tariq, S, Shao, J, Bachagha, N, Yang, R and Yao, Y. 2019. Airborne and spaceborne remote sensing for archaeological and cultural heritage applications: A review of the century (1907-2017). Remote Sensing of Environment, 232: 111280. DOI: https:// doi.org/10.1016/j.rse.2019.111280

Madry, S and Crumley, C. 1990. An application of remote sensing and GIS in a regional archaeological settlement pattern analysis: the Arroux River Valley, Burgundy, France. In: Allen, K, Green, S and Zubrow, E (eds.), Interpreting Space: GIS and Archaeology, 364-380. Bristol, PA: Taylor and Francis.

Magnini, L and Bettineschi, C. 2019. Theory and practice for an object-based approach in archaeological remote sensing. Journal of Archaeological Science, 107: 10-22. DOI: https:// doi.org/10.1016/j.jas.2019.04.005

Magnini, L, Bettineschi, C and De Guio, A. 2017. Object-based Shell Craters Classification from LiDAR-derived Sky-view Factor. Archaeological Prospection, 24(3): 211-223. DOI: https://doi.org/10.1002/arp.1565

Masini, N, Gizzi, F, Biscione, M, Fundone, V, Sedile, M, Sileo, M, Pecci, A, Lacovara, B and Lasaponara, R. 2018. Medieval Archaeology Under the Canopy with LiDAR. The (Re) 
Discovery of a Medieval Fortified Settlement in Southern Italy. Remote Sensing, 10(10): 1598. DOI: https://doi. org/10.3390/rs10101598

McCoy, MD. 2020. The Site Problem: A Critical Review of the Site Concept in Archaeology in the Digital Age. Journal of Field Archaeology, 45(sup1): S18-S26. DOI: https://doi.org/10.108 0/00934690.2020.1713283

Menze, BH, Ur, JA and Sherratt, AG. 2006. Detection of Ancient Settlement Mounds: Archaeological Survey Based on the SRTM Terrain Model. Photogrammetric Engineering \& Remote Sensing, 72(3): 321-327. DOI: https://doi. org/10.14358/PERS.72.3.321

Millican, K. 2012. The Outside Inside: Combining Aerial Photographs, Cropmarks and Landscape Experience. Journal of Archaeological Method and Theory, 19(4): 548563. DOI: https://doi.org/10.1007/s10816-012-9140-9

Nuninger, L, Opitz, R, Verhagen, P, Libourel, T, Laplaige, C, Leturcq, S, Voguer, NL, Fruchart, C, Kokalj, Ž and Rodier, X. 2020a. Developing FAIR Ontological Pathways: Linking Evidence of Movement in Lidar to Models of Human Behaviour. Journal of Computer Applications in Archaeology, 3(1): 63-75. DOI: https://doi.org/10.5334/jcaa.46

Nuninger, L, Verhagen, P, Libourel, T, Opitz, R, Rodier, X, Laplaige, C, Fruchart, C, Leturcq, $\mathbf{S}$ and Levoguer, $\mathbf{N}$. 2020b. Linking Theories, Past Practices, and Archaeological Remains of Movement through Ontological Reasoning. Information, 11(6): 338. DOI: https://doi.org/10.3390/ info11060338

Odling-Smee, FJ, Laland, KN and Feldman, MW. 2003. Niche construction: The neglected process in evolution. Princeton: Princeton University Press.

Oltean, IA and Fonte, J. 2021. GIS Analysis and Spatial Networking Patterns in Upland Ancient Warfare: The Roman Conquest of Dacia. Geosciences, 11(1): 17. DOI: https://doi. org/10.3390/geosciences11010017

Orengo, HA, Conesa, FC, Garcia-Molsosa, A, Lobo, A, Green, AS, Madella, M and Petrie, CA. 2020. Automated detection of archaeological mounds using machine-learning classification of multisensor and multitemporal satellite data. Proceedings of the National Academy of Sciences, 202005583. DOI: https://doi.org/10.1073/pnas.2005583117

Orengo, HA and Garcia-Molsosa, A. 2019. A brave new world for archaeological survey: Automated machine learningbased potsherd detection using high-resolution drone imagery. Journal of Archaeological Science, 105013. DOI: https://doi.org/10.1016/j.jas.2019.105013

Osicki, A and Sjogren, D. 2005. A review of remote sensing application in archaeological research. Geography, 795(28): 333.

Palmer, R. 2020. Computational approaches to archaeological site detection and monitoring: a brief review of a workshop held in Cambridge, 29 February 2020. AARGnews, 60: 25-26.

Parcak, SH. 2009. Satellite Remote Sensing for Archaeology. New York: Routledge. DOI: https://doi. org/10.4324/9780203881460
Pawlowicz, M. 2020. Capturing People on the Move: Spatial Analysis and Remote Sensing in the Bantu Mobility Project, Basanga, Zambia. Afr Archaeol Rev, 37(1): 69-93. DOI: https://doi.org/10.1007/s10437-020-09363-0

Sărășan, A, Ardelean, A-C, Bălărie, A, Wehrheim, R, Tabaldiev, K and Akmatov, K. 2020. Mapping burial mounds based on UAV-derived data in the Suusamyr Plateau, Kyrgyzstan. Journal of Archaeological Science, 123: 105251. DOI: https:// doi.org/10.1016/j.jas.2020.105251

Schiffer, MB. 1983. Toward the Identification of Formation Processes. American Antiquity, 48(4): 675-706. DOI: https:// doi.org/10.2307/279771

Schiffer, MB, Sullivan, AP and Klinger, TC. 1978. The design of archaeological surveys. World Archaeology, 10(1): 1-28. DOI: https://doi.org/10.1080/00438243.1978.9979712

Schneider, A, Takla, M, Nicolay, A, Raab, A and Raab, T. 2015. A Template-matching Approach Combining Morphometric Variables for Automated Mapping of Charcoal Kiln Sites: Automated Mapping of Charcoal Kiln Sites. Archaeological Prospection, 22(1): 45-62. DOI: https://doi.org/10.1002/ arp.1497

Schon, R. 2002. Seeding the landscape: Experimental contributions to regional survey methodology. PhD Dissertation. Bryn Mawr, PA: Bryn Mawr College.

Sevara, C, Pregesbauer, M, Doneus, M, Verhoeven, G and Trinks, I. 2016. Pixel versus object - A comparison of strategies for the semi-automated mapping of archaeological features using airborne laser scanning data. Journal of Archaeological Science: Reports, 5: 485-498. DOI: https://doi.org/10.1016/j.jasrep.2015.12.023

Somrak, M, Džeroski, S and Kokalj, ž. 2020. Learning to Classify Structures in ALS-derived Visualizations of Ancient Maya Settlements with CNN. Remote Sensing, 12(14): 2215. DOI: https://doi.org/10.3390/rs12142215

Sonnemann, T, Comer, D, Patsolic, J, Megarry, W, Herrera Malatesta, E and Hofman, C. 2017. Semi-Automatic Detection of Indigenous Settlement Features on Hispaniola through Remote Sensing Data. Geosciences, 7(4): 127. DOI: https://doi.org/10.3390/geosciences7040127

Soroush, M, Khazraee, E and Ur, JA. 2020. Deep Learning in Archaeological Remote Sensing: Automated Qanat Detection in the Kurdistan Region of Iraq. Remote Sensing, 12(3): 500. DOI: https://doi.org/10.3390/rs12030500

Stephens, L, Fuller, D, Boivin, N, Rick, T, Gauthier, N, Kay, A, Marwick, B, Armstrong, CG, Barton, CM, Denham, T, Douglass, K, Driver, J, Janz, L, Roberts, P, Rogers, JD, Thakar, H, Altaweel, M, Johnson, AL, Sampietro Vattuone, MM, Aldenderfer, M, Archila, S, Artioli, G, Bale, MT, Beach, T, Borrell, F, Braje, T, Buckland, PI, Jiménez Cano, NG, Capriles, JM, Diez Castillo, A, Çilingiroğlu, Ç, Negus Cleary, M, Conolly, J, Coutros, PR, Covey, RA, Cremaschi, M, Crowther, A, Der, L, di Lernia, S, Doershuk, JF, Doolittle, WE, Edwards, KJ, Erlandson, JM, Evans, D, Fairbairn, A, Faulkner, P, Feinman, G, Fernandes, R, Fitzpatrick, SM, Fyfe, R, Garcea, E, Goldstein, S, Goodman, RC, Dalpoim Guedes, J, Herrmann, J, Hiscock, P, Hommel, 
P, Horsburgh, KA, Hritz, C, Ives, JW, Junno, A, Kahn, JG, Kaufman, B, Kearns, C, Kidder, TR, Lanoë, F, Lawrence, D, Lee, G-A, Levin, MJ, Lindskoug, HB, López-Sáez, JA, Macrae, S, Marchant, R, Marston, JM, McClure, S, McCoy, MD, Miller, AV, Morrison, M, Motuzaite Matuzeviciute, G, Müller, J, Nayak, A, Noerwidi, S, Peres, TM, Peterson, CE, Proctor, L, Randall, AR, Renette, S, Robbins Schug, G, Ryzewski, K, Saini, R, Scheinsohn, V, Schmidt, P, Sebillaud, P, Seitsonen, O, Simpson, IA, Sołtysiak, A, Speakman, RJ, Spengler, RN, Steffen, ML, Storozum, MJ, Strickland, KM, Thompson, J, Thurston, TL, Ulm, S, Ustunkaya, MC, Welker, MH, West, C, Williams, PR, Wright, DK, Wright, N, Zahir, M, Zerboni, A, Beaudoin, E, Munevar Garcia, S, Powell, J, Thornton, A, Kaplan, JO, Gaillard, M-J, Klein Goldewijk, K and Ellis, E. 2019. Archaeological assessment reveals Earth's early transformation through land use. Science, 365(6456): 897-902. DOI: https://doi.org/10.1126/ science.aax1192

Steward, J. 1955. Smallholders, householders: Farm Families and the Ecology of Intensive, Sustainable Agriculture. In: Haenn, $\mathrm{N}$ and Wilk, R (eds.), Anthropological Theory: An Introductory History, 1-9. New York: New York University Press.

Steward, JH. 1937. Ecological Aspects of Southwestern Society. Anthropos, 32(1/2): 87-104.

Thabeng, OL, Adam, E and Merlo, S. 2019. Spectral Discrimination of Archaeological Sites Previously Occupied by Farming Communities Using In Situ Hyperspectral Data. Journal of Spectroscopy, 2019: 1-21. DOI: https://doi. org/10.1155/2019/5158465

Thabeng, OL, Merlo, S and Adam, E. 2019. High-resolution remote sensing and advanced classification techniques for the prospection of archaeological sites' markers: The case of dung deposits in the Shashi-Limpopo Confluence area (southern Africa). Journal of Archaeological Science, 102: 48-60. DOI: https://doi.org/10.1016/j.jas.2018.12.003

Thabeng, OL, Merlo, $\mathbf{S}$ and Adam, E. 2020. From the Bottom Up: Assessing the Spectral Ability of Common Multispectral Sensors to Detect Surface Archaeological Deposits Using Field Spectrometry and Advanced Classifiers in the ShashiLimpopo Confluence Area. African Archaeological Review. DOI: https://doi.org/10.1007/s10437-020-09372-z

Thomas, J. 1993. The Politics of Vision and the Archaeologies of Landscape. In: Bender, B (ed.), Landscape: Politics and Perspectives, 19-48. Oxford: Berg.

Thompson, VD, Arnold, PJ, Pluckhahn, TJ and VanDerwarker, AM. 2011. Situating Remote Sensing in Anthropological Archaeology. Archaeological Prospection, 18(3): 195-213. DOI: https://doi.org/10.1002/arp.400

Traviglia, A and Torsello, A. 2017. Landscape Pattern Detection in Archaeological Remote Sensing. Geosciences, 7(4): 128. DOI: https://doi.org/10.3390/geosciences7040128

Trier, ØD, Cowley, DC and Waldeland, AU. 2019. Using deep neural networks on airborne laser scanning data: Results from a case study of semi-automatic mapping of archaeological topography on Arran, Scotland. Archaeological Prospection, 26(2): 165-175. DOI: https://doi.org/10.1002/arp.1731

Trier, ØD, Larsen, $\mathbf{\varnothing}$ and Solberg, R. 2009. Automatic detection of circular structures in high-resolution satellite images of agricultural land. Archaeological Prospection, 16(1): 1-15. DOI: https://doi.org/10.1002/arp.339

Trier, ØD, Reksten, JH and Løseth, K. 2021. Automated mapping of cultural heritage in Norway from airborne lidar data using faster R-CNN. International Journal of Applied Earth Observation and Geoinformation, 95: 102241. DOI: https://doi.org/10.1016/j.jag.2020.102241

Verhagen, $\mathbf{P}$ and Whitley, TG. 2012. Integrating Archaeological Theory and Predictive Modeling: a Live Report from the Scene. Journal of Archaeological Method and Theory, 19(1): 49-100. DOI: https://doi.org/10.1007/s10816-011-9102-7

Verhoeven, G. 2017. Are We There Yet? A Review and Assessment of Archaeological Passive Airborne Optical Imaging Approaches in the Light of Landscape Archaeology. Geosciences, 7(3): 86. DOI: https://doi. org/10.3390/geosciences7030086

Verhoeven, GJ. 2012. Near-Infrared Aerial Crop Mark Archaeology: From its Historical Use to Current Digital Implementations. Journal of Archaeological Method and Theory, 19(1): 132-160. DOI: https://doi.org/10.1007/ s10816-011-9104-5

Verschoof-van der Vaart, WB and Lambers, K. 2019. Learning to Look at LiDAR: The Use of R-CNN in the Automated Detection of Archaeological Objects in LiDAR Data from the Netherlands. Journal of Computer Applications in Archaeology, 2(1): 31-40. DOI: https://doi.org/10.5334/jcaa.32

Verschoof-van der Vaart, WB and Landauer, J. 2020. Using CarcassonNet to automatically detect and trace hollow roads in LiDAR data from the Netherlands. Journal of Cultural Heritage, S1296207420304805. DOI: https://doi. org/10.1016/j.culher.2020.10.009

Vining, BR. 2018. Cultural Niche Construction and Remote Sensing of Ancient Anthropogenic Environmental Change in the North Coast of Peru. Journal of Archaeological Method and Theory, 25(2): 559-586. DOI: https://doi.org/10.1007/ s10816-017-9346-y

Wang, S, Hu, Q, Wang, F, Ai, M and Zhong, R. 2017. A Microtopographic Feature Analysis-Based LiDAR Data Processing Approach for the Identification of Chu Tombs. Remote Sensing, 9(9): 880. DOI: https://doi.org/10.3390/ rs9090880

Wilson, DR. 1975. Aerial reconnaissance for archaeology. London: Council for British archaeology.

Yaworsky, PM and Codding, BF. 2018. The Ideal Distribution of Farmers: Explaining the Euro-American Settlement of Utah. American Antiquity, 83(01): 75-90. DOI: https://doi. org/10.1017/aaq.2017.46

Yaworsky, PM, Vernon, KB, Spangler, JD, Brewer, SC and Codding, BF. 2020. Advancing predictive modeling in archaeology: An evaluation of regression and machine learning methods on the Grand Staircase-Escalante National Monument. PLOS ONE, 15(10): e0239424. DOI: https://doi.org/10.1371/journal.pone.0239424 
TO CITE THIS ARTICLE:

Davis, D. 2021. Theoretical Repositioning of Automated Remote Sensing Archaeology: Shifting from Features to Ephemeral Landscapes. Journal of Computer Applications in Archaeology, 4(1), 94-109. DOI: https://doi.org/10.5334/jcaa.72

Submitted: 15 March 2021 Accepted: 16 April 2021 Published: 11 May 2021

COPYRIGHT:

(c) 2021 The Author(s). This is an open-access article distributed under the terms of the Creative Commons Attribution 4.0 International License (CC-BY 4.0), which permits unrestricted use, distribution, and reproduction in any medium, provided the original author and source are credited. See http://creativecommons.org/licenses/by/4.0/.

Journal of Computer Applications in Archaeology is a peer-reviewed open access journal published by Ubiquity Press.

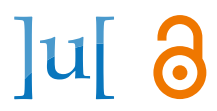

